$021000-0020-92-147$
$007-54-054$

UNCLASSIFIED
DP -129

Instrumentation

\title{
IODINE STACK MONITOR
}

by

B. M. Carmichael and D. G. Karraker

Instrument Development Division

August 1955

$\cos ^{2}$

$P_{1}$

(

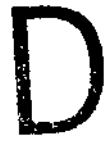

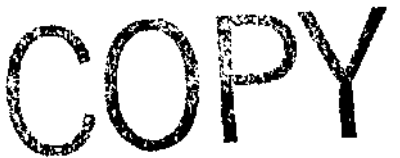

DO NOT RELEASE

FROM FILE

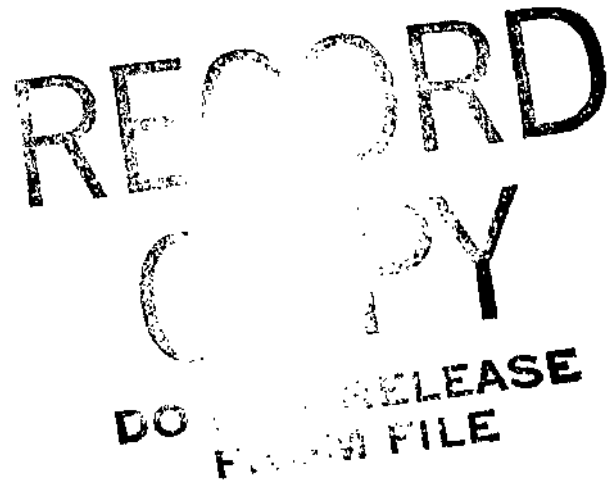

E. I. du Pont de Nemours \& Co.

Explosives Department - Atomic Energy Division Technical Division - Savannah River Laboratory 


\section{IODINE STACK MONITOR}

\section{by}

B. M. Carmichael and D. G. Karraker Instrument Development Division

August 1955

E. I. du Pont de Nemours \& Co.

Explosives Department - Atomic Energy Division Technical Division - Savannah River Laboratory

Printed for

The United States Atomic Energy Commission

Contract AT $(07-2)-1$ 


\begin{abstract}
An instrument for continuously monitoring radio-iodine in a flowing caustic solution was assembled for use with a stack

monitoring system. An absolute counting efficiency of 3.2 per cent was obtained.
\end{abstract}

External Distribution according to TID 4500 (9th Ed.) 


\section{INTERNAL DISTRIBUTION}

No. of Coples

(5) AEC, SROO Augusta, Ga.

(1) R. M. Evans -
B. H. Mackey
W1imington AED

(I) J. E. Cole - M. H. Smith -

Engineering Department

Savannah River Plant

J. B. Tinker

(I) H. Worthington

(1) V.R. Thayer

(I) "W" File

(I) S. I. Winde

(1) J. D. Ellett

R. H. Dietz

(1) L. S. Danser

(1) L. C. Peery

(1) W. P. Overbeck -

T. C. Evans

(1) C. M. Patterson -

E. I. Karlson

(1) W. B. Watkins

I) J. D. CIst - W. A. Kropp

Savannah

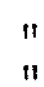

i1

W. M. Eaton -

G. M. Crooks

(1) J.J. Monahon

(1) PRD File

"

"

I"

"

(I) M. H. Wahl -

C. W. J. Wende

(1) G. Dessauer

(1) J. W. Morris -

W. P. Bebbington

(1) R. I. Martens

(I) J.N.Wilson

I I. Cathey

(1) B. 3. Johnson

(1) B. M. Carmichael -

D. G. Karraker

(15) TIS File

(i) TIS File Record Copy
Savannah River Laboratory

11
11
11
11
$" 1$
11


D) P-129-External Distribution Mailed

No. of Copies 


\section{INS'TRUMEN'TA TION (Cont'd.)}

No. of Copies

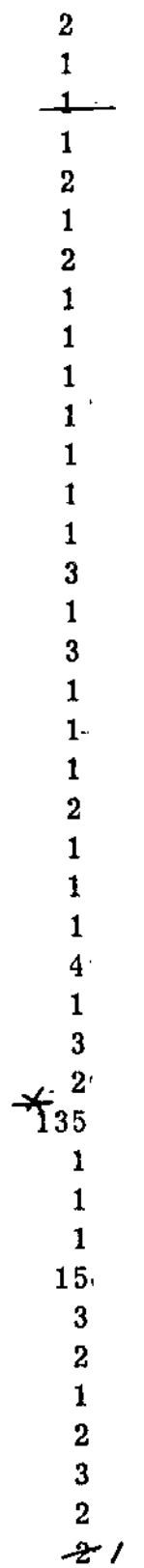

3

1

1

300
Iowa State College

Italy, Centro Informazioni Studi Esperienze.

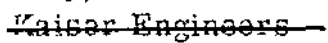

Kirtland Air Force Base

Knolls Atomic Power Laboratory

Lockheed Aircraft Corporation

Los Alamos Scientific Laboratory

Mallinckrodt Chemical Works

Hound Laboratory

National Advisory Committee for Aeronautics, Cleveland National Bureau of Standards, Atomic Energy Project

riational Bureau of Standards (Library)

Wational Lead Company of Ohio

National Research Corporation

National Research Council, Canada :

Naval Medical Research Institute

Naval Research Laboratory

New Brunswick Laboratory

Newport News Shipbuilding and Dry Dock Company

New York Operations Office

North American Aviation, Inc.

INuclear Development issociates, Inc.

Wuclear Metals, Inc. (Dr. Kaufmann)

Dak Ridge Institute of Nuclear Studies

Phillips Petroleum Company

Princeton University

Public Health Service

Sandia Corporation

Technical Information Service, Oak Ridge

the Surgeon General

Tokyo University .

United Aircraft Corporation

United Kingdom Scientific Mission

U. S. Geological Survey (RCS-TEPCO), Denver

U. S. Naval Radiological Defense Laboratory

UCLA Medical Research Laboratory

University of California Radiation Laboratory, Berkeley

University of California Radiation Laboratory, Livermore

L tiversity of Michigan (Dr. Gomberg)

University of Rochester, Atomic Energy Project

University of Utah

University of W/ashington (Dr. Donaldson)

Vitro Corporation of America

Walter Kidde Nuclear Laboratories, Inc.

Watertown Aisenal

Weil, Dr. George L.

Western Reserve University

Westinghouse Electric Corporation

Yale University (Dr. Wadey)

Signal Corps ENGINeering Laboratories

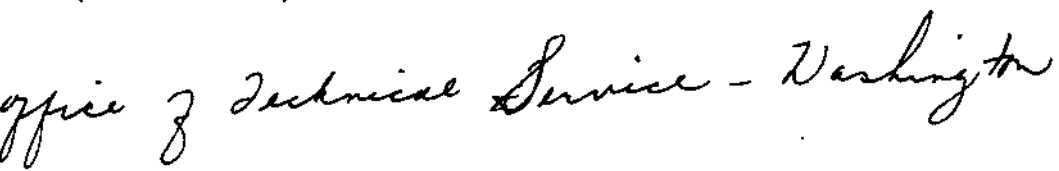




\section{TABLE OF CONTENTS}

\section{Page}

INTRODUCTION

4

SUMMARY

4

DISCUSSION

5

Measurement of Counting Efficiency

Operating Range of the Monitor

Design of Counting Chamber and Shield

Counting Equipment

\section{LIST OF FIGURES}

\section{Figure}

1 Activity Chamber, Probe, and Shield

2 Block Diagram of Counting Equipment 


\section{IODINE STACK MONITOR}

\section{INTRODUCTION}

Small amounts of fission-product lodine may be released to the atmosphere during the dissolving of irradiated uranium. A monitor is necessary to establish that the amount of radioactive iodine discharged from the stack is within an allowable range.

The monitoring system employs a small caustic scrubber that continuously samples the exhaust air from the stack. This report covers the development and calibration of the counting system which is used to monitor the radioactive lodine in the caustic stream.

\section{SUMMARY}

A logarithmic count rate system was assembled from commerclal components to monitor the radioactive lodine sampled from the discharge of the stack. The sample cell and shield were fabricated in the laboratory. The electronic system responds rapidiy to changes in the amount of lodine present in the caustic stream.

The absolute efficiency of the counting arrangement is 3.2 per cent for caustic samples spiked with radio-iodine 131 . The logarithmic recorder scale reads from 100 to 10,000 counts/minute, corresponding to 0.88 to $216.5 \mu \mathrm{c} /$ day of $\mathrm{I}-131$ absorbed by the scrubber. 


\section{DISCUSSION}

In the iodine stack-monitor system a portion of the air exhausted up the stack is run through a scrubber which removes the lodine with 0. IN NaOH. The $\mathrm{NaOH}$ solution is passed through a counting chamber and the iodine is counted. by a scintiliation counter. The count obtained by the scintillation counter is proportional to the lodine activity flowing up the stack, and gives an indication of the instantaneous level of lodine activity exhausted by the stack. The NaOH solution of radioactive iodine leaves the counting chamber and flows to a catch tank where the solution is sampled and analyzed every 24 hours to allow calculation of the total amount of iodine exhausted in that day.

To establish the proper size of the caustic scrubber, the counting efficiency in the proposed sample cell had to be measured, since this efficiency determined the magnitude of the sample air stream.

\section{MEASUREMENT OF COUNTING EFEICIENCY}

Isotopically pure II3I in solution with $\mathrm{Na}_{2} \mathrm{SO}_{3}$ was obtained from Oak Ridge, diluted in a solution of $\mathrm{NaOH}$ by a factor of $10^{4}$, and counted in a counting chamber. A scintillation crystal NaI(TI), a G.E. scintillation probe unit, and a Tracerlab CC-10 scaler comprised the counting equipment.

The experimental counting chamber was a right cylinder made of brass, 4 $\mathrm{cm}$ in diameter and $2 \mathrm{~cm}$ high (internal dimensions), which held about 25 cc of solution. One face of the cylinder was a brass "window, "0.12 mm thick, through which the lodine radiation passed. The counter was shielded with two inches of lead bricks.

After the solution was counted in the experimental chamber, the activity level was determined by plating a sample and counting it in a windowless pro-. portional counter (Nuclear Measurements PCC-10).* The counting efficiency calculated from these measurements was 3.2 per cent. Corrections for dead-time losses in the counting rates were included.

\section{OPERATING RANGE OF THE MONITOR}

A fraction of the exhaust air in the stack is drawn by vacuum from sample points in the stack into a caustic scrubber. This gas sample is fea into a 3 -foot column packed with 1/4-inch x 1/4-inch Raschig rings to a depth of 12 inches and is contacted with $0.1 \mathrm{~N}(0.4$ per cent) $\mathrm{NaOH}$ at a flow rate of $20 \mathrm{ml} / \mathrm{min}$. Under these conditions of flow rate, it is calculated that a uniform rate of $2.5 \mathrm{\mu c} /$ day of lodine into the scrubber will yield $145 \mathrm{dis} / \mathrm{min} / \mathrm{ml}$ in the caustic effluent, provided that the scrubber efficiency is 75 per cent.

Since the volume of the lodine counting chamber is $25 \mathrm{cc}$ and the absolute counting efficiency is 3.2 per cent, the average counting rate will be $115 \mathrm{c} / \mathrm{m}$ for an average rate of $2.5 \mathrm{\mu c} /$ day of lodine into the scrubber.

\section{DESIGN OF COUNTING CHAMBER AND SHIELD}

The detecting unit is composed of a counting chamber through which the $\mathrm{NaOH}$ flows for monitoring, and a G.E. scintillation probe, all housed in a lead shield as shown in Figure 1. The minimum level of detection is considered to be 50 per cent of the background count. Since the background for a normal unit is about $60 \mathrm{c} / \mathrm{m}$ in the lead shield, this background restricts the detectable limit to $30 \mathrm{c} / \mathrm{m}$, which amounts to a rate of $0.65 \mu \mathrm{c} /$ day of iodine entering the scrubber.

The counting chamber is dimensionally identical ( $4 \mathrm{~cm}$ I.D. and $2 \mathrm{~cm} \mathrm{high}$ ) with the chamber that was used to determine the counting efficiency. However, the

* Prohaska, C. A. The SRP Standard Window Iess Flow Counter. Nemours \& Co., DP-45, April 1954.

E. I. du Pont de 
material used in its construction is \#347 stainless steel to eliminate corrosion. The steel window has almost the same density as the experimental brass window.

The lead shield is 2 inches thick; it is composed of flve lead "doughnuts" which are 4 inches high, 6-1/2 inches in diameter, with 2-inch walls. The tops and bottoms of the doughnuts are inclined at an angle of $30^{\circ}$ to avoid cracks at the joints. Each doughnut welghs about fifty pounds. Top and bottom plates for the assembly fit on the angled sides of the doughnuts. The counting chamber is placed at the bottom of the shield, with the pipes for the flowing NaOH entering at the bottom of the shield and leaving through the side. Cables for the scintillation probe leave the shield through a groove at the junction of the top plate vertical adjustment of the position screw through the bottom lead doughnut permits COUNTING EQUIPMENT

A block diagram of the counting system is shown in Figure 2. The equipment consists of a standard G.E. scintiliation probe, an Atomic Model 316 highvoltage supply for the G.E. probe, an Atomic Model $204 B$ linear amplifier, an RCL log count rate meter, and a Brown recorder. Filament current and plate voltage for the probe preamplifier are obtalned from the linear amplifier. The output of the preamplifier is fed into the linear amplifier which in turn drives the $10 \mathrm{~g}$ the Brown recorder. The output of. the log count rate meter is monitored remotely by
the rate meter.

The location of the log count rate meter, linear amplifier, and the high-voltage source is not critical, but should be within twenty feet of the preamplifier. Coaxial cables should be used for the high-voltage and stgnal cables, since an objectionable amount of "noise" may appear otherwise. A "Sola" constant voltage transformer is used to reduce fluctuations in the Iine voltage.

In laboratory tests the discriminator on the linear amplifier was adjusted to provide the maximum counting rate consistent with a reasonable background. The log count rate meter and Brown recorder were calibrated by feeding pulses from a pulse generator into the log count rate meter. The pulse repetition rates indicated by the meter and recorder were then adjusted to obtain agreement

Long-time drifts in the instrument system were studied over a two-week interval with a flxed test source. Drifts of the order of flve per cent per day were observed. The calibration of the circuit needs to be checked once in each 24 -hour period by means of the 60 -cycle calibration point provided on the $10 \mathrm{~g}$
count rate meter.

The monitor recorder has a three-decade logarithmic scale to match the log count rate meter. Since the background is about $60 \mathrm{c} / \mathrm{m}$ and since $2.5 \mu \mathrm{c} /$ day of lodine into the $\mathrm{NaOH}$ scrubber is expected to give $115 \mathrm{c} / \mathrm{m}$, the recorder scale calibration is approximately as follows:

$$
\begin{array}{r}
100 \mathrm{c} / \mathrm{m} \\
1,000 \\
10,000
\end{array}
$$

The exact calibration depends on field conditions.

$$
\begin{aligned}
& 0.88 \mu \mathrm{c} / \text { day into scrubber } \\
& 20.3 \\
& 216.5
\end{aligned}
$$

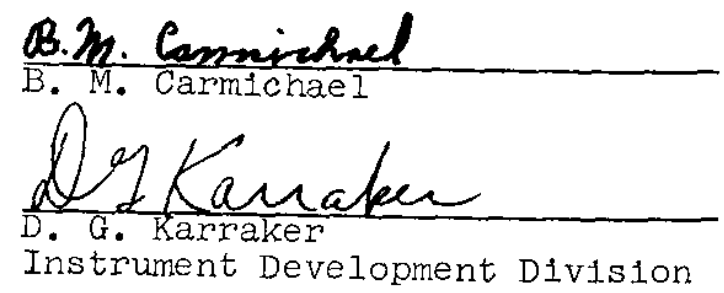




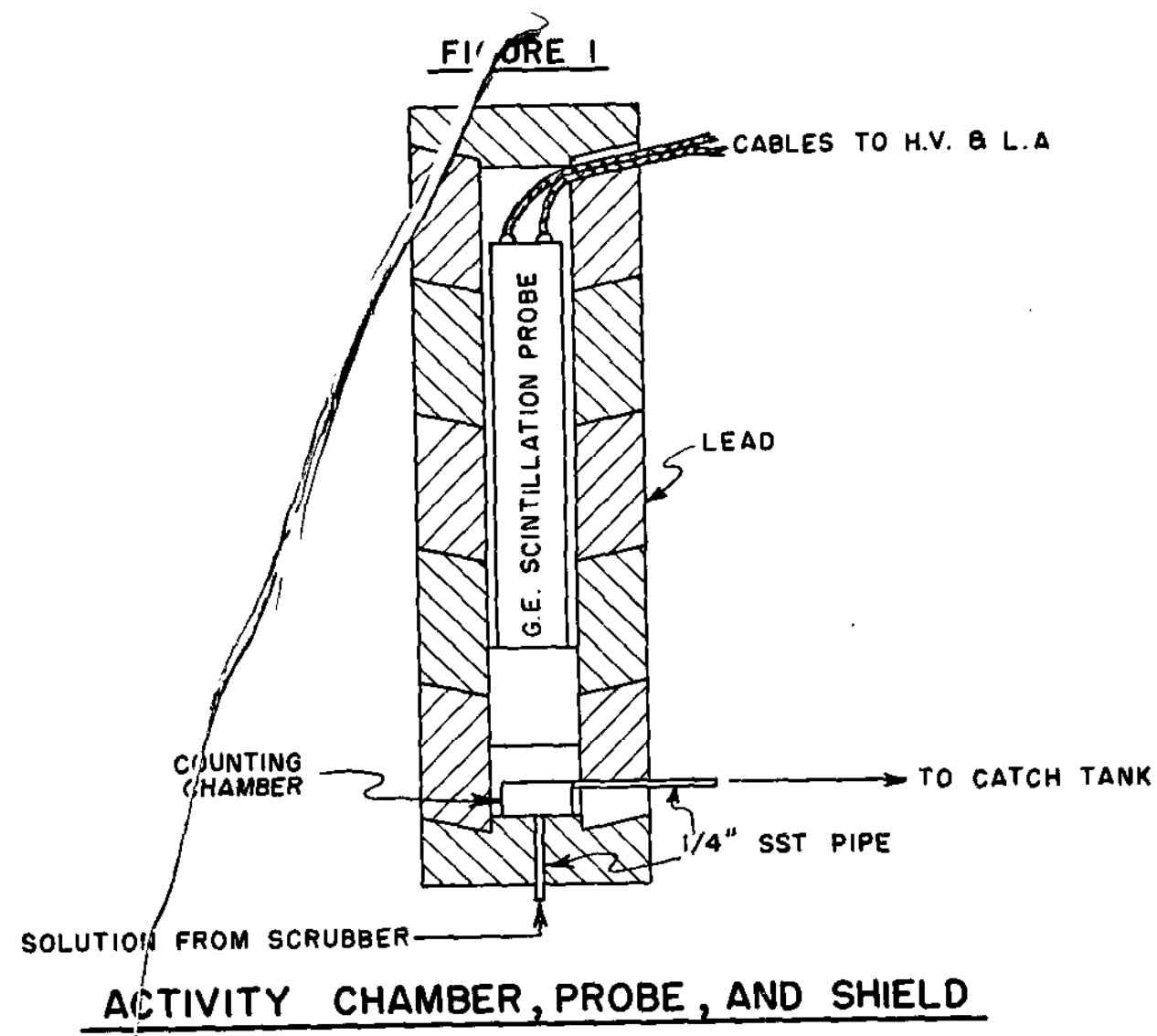

FIGURE 2

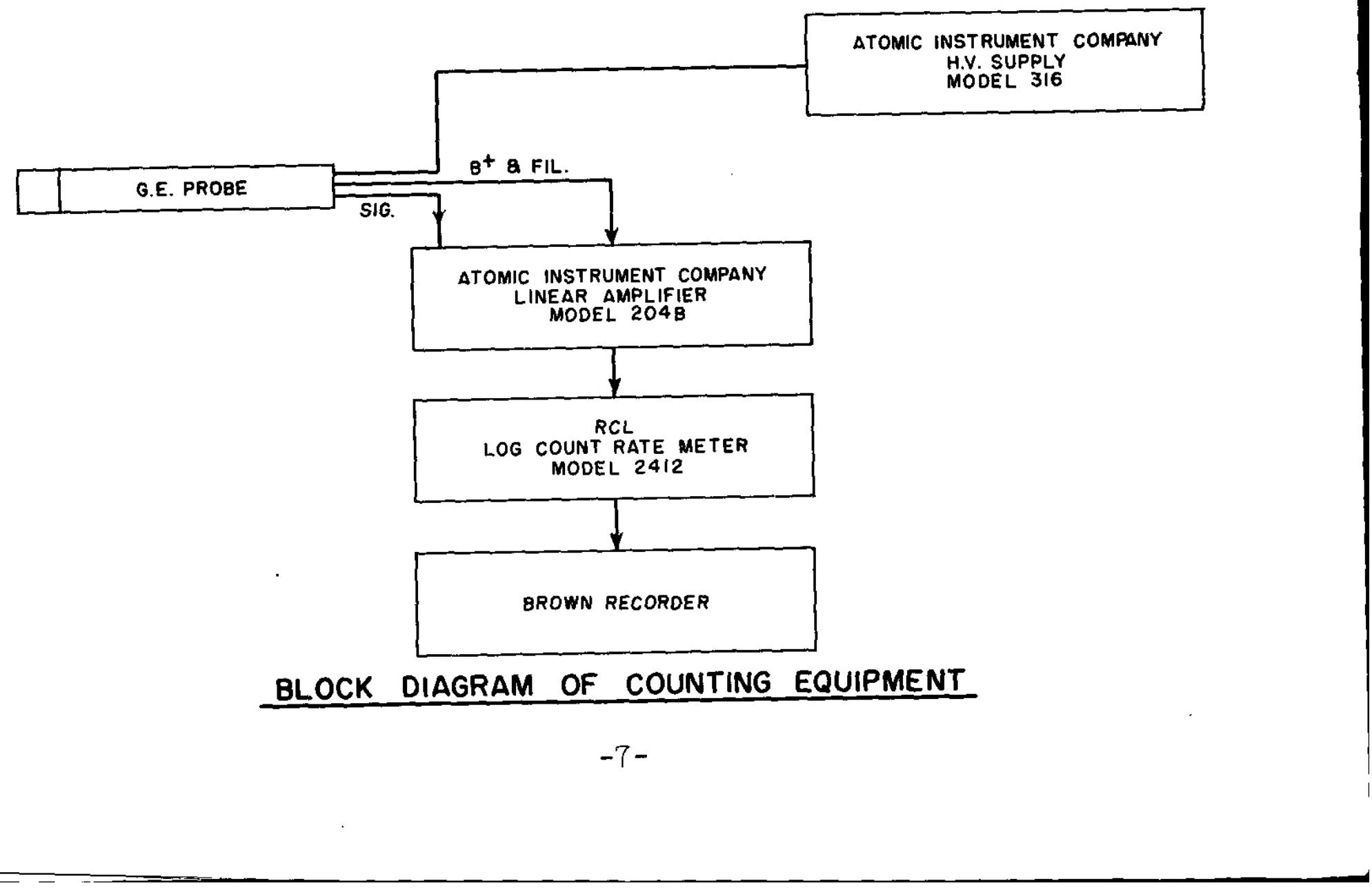

